\title{
Notes
}

\section{Judicial Intervention and Organization Theory: Changing Bureaucratic Behavior and Policy}

In recent years, the judicial role in public policy has greatly expanded: courts have been actively involved in the administration of penal, welfare, education, mental health, and environmental protection policies. ${ }^{1}$ In remedying perceived wrongs, they have had to interact with the public bureaucracies operating in the particular policy arenas affected. Judges have not sought merely to monitor the activities of these institutions but have attempted to restructure them, to change their processes and policies.

Numerous commentators have discussed whether courts are wellequipped to intervene in matters of policy and administration. ${ }^{2}$ After briefly reviewing that debate, this Note argues that its focus has largely been misdirected. The principal concern should not be with determining whether courts can make use of apparatuses to assist in the decisionmaking process, but with preparing judges for the task of restructuring bureaucracies. If a remedy is to be effective, then a judge designing relief must take into account the nature of the organizations whose policies and processes he seeks to alter. A court must appreciate the limits of institutional capacity as well as the opportunities for change. Only if it does so can the judiciary act creatively to rectify injustice and to preserve the exercise of rights. The Note contends that organization theory can provide an instructive frame-

1. See, e.g., Beal v. Lindsay, 468 F.2d 287 (2d Cir. 1972) (municipal services); Rhem v. Malcolm, 371 F. Supp. 594 (S.D.N.Y.), supplemented, 377 F. Supp. 995 (S.D.N.Y.), aff'd in part, remanded in part, 507 F.2d 333 (2d Cir. 1974) (prisons); Wyatt v. Stickney, 344 F. Supp. 373 (M.D. Ala.), supplemented, 344 F. Supp. 387 (M.D. Ala. 1972), aff'd in part, rev'd in part sub nom. Wyatt v. Aderholt, 503 F.2d 1305 (5th Cir. 1974) (mental health).

2. Compare Chayes, The Role of the Judge in Public Law Litigation, 89 Harv. L. REv. 1281, 1308 (1976) (courts may have institutional advantages in restructuring institutions) and Special Project, The Remedial Process in Institutional Reform Litigation, 78 CoLum. L. REv. 783, 821-42 (1978) (examining administrative techniques that courts can use) with D. Horowitz, The CourTs and Socral Policy 33-56 (1977) (discussing limits of judicial process) and Glazer, Should Judges Administer Social Services? 50 PUB. INTEREST 64 (1978) (arguing courts ill-suited to tasks of social intervention). 
work that will aid a judge in initially predicting the administrative feasibility of a proposed remedy, in fashioning workable relief, and then in implementing the chosen plan. After presenting the framework, the Note demonstrates its utility by applying it to Hart v. Community School Board, ${ }^{3}$ a case in which a court redesigned an educational institution to achieve integration.

\section{The Capacity of Courts to Intervene}

To fashion effective changes in policy and administration, decisionmakers must be able to collect information, assess various alternatives, monitor the implementation process, and secure the compliance of the targeted bureaucracies. ${ }^{4}$ Commentators have vigorously debated whether judges have the capacity to perform such tasks. ${ }^{5}$ According to many observers, the judiciary is ill-equipped to intervene in matters of policy and administration, even when important rights are being violated. These commentators allege that courts are incapable of collecting and interpreting the data needed to determine whether and how to alter the programs and processes of public bureaucracies ${ }^{0}$ be-

3. 383 F. Supp. 699 (E.D.N.Y.) (liability decision and subsequent order selecting special master), supplemented, 383 F. Supp. 769 (E.D.N.Y. 1974) (remedial order), aff'd, 512 F.2d 37 (2d Cir. 1975).

4. See Y. Dror, Public Policymaking Reexamined 163-96 (1968) (all models of public administration and public policy make provision for data gathering, policy assessment, and monitoring).

5. Compare Chayes, supra note 2 (favorably assessing courts' capacity to intervene) and Fiss, The Supreme Court, 1978 Term-Foreword: The Forms of Justice, 93 HARv. $L$. Rev. 1 (1979) (same) with A. Bickel, The Supreme Court and the IdeA of Progress 81181 (1970) (questioning capacity of courts to remake social policy) and $L$. GraGLIA, DISASTER BY DECREE (1976) (examining problems of court-ordered school desegregation). Some commentators are ambivalent about judicial capacity. See Cox, The New Dimensions of Constitutional Adjudication, 51 WAsr. L. REv. 791 (1976) (viewing court intervention as necessary, but doubting whether judicial procedures and personnel are suited to tasks of institutional reform).

6. See D. Horowrr, supra note 2 , at 48 (adversary method could stifle introduction of relevant information if litigants skillfully use rules of evidence); P. Rosen, THE SuPREME CourT AND Social ScIENCE 202 (1972) (same). See generally Hazard, Limitations on the Uses of Behavioral Science in the Law, 19 CASE W. REs. L. REv. 71 (196') (problems preventing effective application of social science).

It is also charged that judges may not have the expertise to evaluate information that is admitted. See, e.g., Levin, Education, Life Chances, and the Courts: The Role of Social Science Evidence, 39 Law \& Contemp. Prob. (No. 2) 217, 240 (1975); Moynihan, Social Science and the Courts, 54 PuB. INTEREst 12, 15 (1979).

One observer contends that the judiciary errs in relying too heavily on "theoretical" knowledge offered by academic experts, rather than on information supplied by practitioners who may be in a better position to know of the limitations of the state of social science. See Glazer, supra note 2, at 78-79.

Finally, critics argue that because the courts' information is filtered through the 
cause adjudicatory decisionmaking is piecemeal and reactive. ${ }^{7}$

Critics of judicial intervention further maintain that because adjudication is concerned with legal relationships-rights and obligations-judges generally overlook the feasibility of remedies ${ }^{8}$ and thus do not try to ascertain how decisions will affect, or be affected by, the broader social and political milieu. ${ }^{9}$ They also charge that even if a judge wants to be attentive to remedial issues, he lacks the machinery to uncover unintended consequences and to correct errors. ${ }^{10}$ Finally, commentators have stated that courts make decisions that are better left to elected officials, whose actions reflect the value preferences of their constituents. ${ }^{11}$ Courts are imperial in imposing their uninformed

prisms of self-interested parties, judges may not have access to all relevant data. See B. Moore, Reflections on the Causes of Human Misery 95-96 (1972) (defense lawyer will not admit that new evidence offered by prosecution is valid if it hurts client); Wolf, Social Science and the Courts: The Detroit Schools Case, 42 PUB. INTEREST 102, 111 (1976) (parties were less than candid in presenting all relevant information).

7. See, e.g., J. Gray, The Nature and Sources of the Law 114-15 (1921) (judges "determine duties and corresponding rights upon the application of persons claiming those rights") (emphasis in original); P. Kurland, Polmics, the Constitution and tHE WARREN CoURT 196 (1970) (judges unable to initiate and conduct own inquiries).

8. See D. Horowrrz, supra note 2, at 34 (questions of feasibility are thought minor or unimportant); Glazer, supra note 2, at 74 (same).

9. D. HoRowitz, supra note 2, at 35; cf. A. Bickel, supra note 5, at 175 (1970) (judicial process "too remote from conditions, and deals, case by case, with too narrow a slice of reality" and thus "it is, in a vast, complex, changeable society, a most unsuitable instrument for the formation of policy"); Fuller, The Forms and Limits of Adjudication, 92 HARv. L. REV. 353, 395.96 (1978) (courts ill-equipped to resolve "polycentric" problems).

Unlike legislators and administrators, judges, the argument proceeds, are not conscious of the budgetary constraints that affect policy choices. They make decisions without the administrator's or legislator's concern for the trade-offs among many programs that have to be made when resources are limited. See Frug, The Judicial Power of the Purse, 126 U. PA. L. REv. 715, 788 (1978); Thomas, Have the Judges Done Too Much? Time, Jan. 22, 1979, at 91 (quoting Professor Paul Freund as stating: "Courts . . . see problems through a keyhole. What they ordain in the way of expenditures is not correlated with expenditures for other needs.")

10. D. Horowrtz, supra note 2, at 53; Wells \& Grossman, The Concept of Judicial Policy-Making: A Critique, 15 J. PUB. L. 286, 305 (1966).

If the parties do not inform the courts of implementation problems, perhaps owing to a lack of resources, then the courts may never attend to those difficulties. See Howard, Adjudication Considered as a Process of Conflict Resolution: A Variation on Separation of Powers, 18 J. PuB. L. 339, 367-68 (1969). Conceivably, write some observers, suits or follow-up actions might arise after so much damage has been done that an effective remedy cannot be fashioned. D. HoRowitz, supra note 2, at 39; Wells \& Grossman, supra, at 303.

11. See Glazer, Towards an Imperial Judiciary, 41 PUb. INTEREST 104, 118, 122 (1975); cf. A. Cox, The Role of the Supreme Court in American Government 103 (1976) ("excessive reliance upon courts instead of self-government through democratic processes may deaden a people's sense of moral and political responsibility for their own future"); Frug, supra note 9 , at 742 (shift of power away from elected officials weakens democratic accountability); Nagel, Federal Equitable Remedies, 30 STAN. L. REv. 661, 718-23 (1978) (judicial assumption of legislative and executive tasks violates separation of powers doctrine). 
views on bureaucracies; ${ }^{12}$ therefore their remedies may be met with intransigence. ${ }^{13}$

Such criticisms are, for the most part, oversimplified; courts are not necessarily ill-equipped to intervene in matters of policy and administration. ${ }^{14}$ The judiciary does not have to be passive or suffer from information insularity. To facilitate the gathering of data and the weighing of remedial options, judges have made use of hearings ${ }^{15}$ at which they have been exposed to differing views from theorists as well as practitioners. ${ }^{16}$ They can also undertake off-the-bench research, ${ }^{17}$ appoint special masters, ${ }^{18}$ expert witnesses, and consultants, ${ }^{19}$ and make use of amicus briefs..$^{20}$ Judges can be made aware of the uses ${ }^{21}$ and

12. Glazer, supra note 11 , at 104-24. Relatedly, critics of judicial intervention claim that by reducing the power and responsibility of administrators, courts decrease the discretion of those bureaucrats who are most familiar with the existing situation. See Rizzo v. Goode, 423 U.S. 362, 378-80 (1976) (assumes bureaucracy has superior knowledge of its own affairs and thus should not be limited by courts in dispatch of own internal affairs).

Moreover, it is alleged that such court action undermines-the authority of bureaucrats because it reinforces the public's and recipients' lack of confidence in the administrator. Glazer, supra note 2, at 76. Consequently, the morale of the bureaucrats is likely to suffer. See Bershad, The Law and Corrections: $A$ Management Perspective, 4 NEw ENG. J. PRIson L. 49, 60-61 (1977) (stating that correctional reform cases have demoralized correction officials).

13. See Morgan v. McDonough, 540 F.2d 527, 532 (1st Cir. 1976), cert. denied, 429 U.S. 1042 (1977) (opposition from faculty and administration to court's desegregation decrees).

14. For views of judges advocating an active role, see Frankel, The Adversary Judge, 54 TEx. L. Rev. 465 (1976); Johnson, Observation: The Constitution and the Federal District Judge, 54 TEx. L. Rev. 903 (1976).

15. See Hart v. Community School Board, 383 F. Supp. 699 (E.D.N.Y.), supplemented, 383 F. Supp. 769 (E.D.N.Y. 1974), aff'd, 512 F.2d 37 (2d Cir. 1975); FED. R. Evid. 614 (court's power to call and examine witnesses).

16. See note 80 infra (social scientists and practitioners testifying in Hart case).

So that lawyers and judges might be able to evaluate data with greater facility, legal education should include training in basic concepts of analytical methods. See Lasswell \& McDougal, Legal Education and Public Policy: Professional Training in the Public Interest, 52 YALE L.J. 203, 204-06 (1943) (calling for such training); Moynihan, supra note 6, at 30 (discussing need for exposing attorneys to basic analytical concepts).

17. See A. Bickel, The UnPublished OpINions of Mr. Justice Brandeis xvii-xivii (1957) (Brandeis viewed briefs and arguments as starting point and drew heavily on library sources).

18. See FED. R. Giv. P. 53(2) (power of courts to appoint masters); Fiss, supra note 5 , at 56 (noting that special master can serve not only as auxiliary spokesman in structural litigation, but also as intermediate structure standing between judge and organization and between judge and body politic); Kaufman, Masters in the Federal Courts: Rule 53, 58 Colum. L. Rev. 452 (1958) (examining masters); Note, "Mastering" Intervention in Prisons, 88 YALE L.J. 1062 (1979) (examining role of masters in prison litigation).

19. See FED. R. Evid. 706 (power of courts to appoint experts).

20. See Krislov, The Amicus Curiae Brief: From Friendship to Advocacy, 72 YAlE L.J. 694 (1963) (examining how courts use amicus briefs to secure information and foster group participation in decisionmaking process).

21. See, e.g., Cottrell, The Interrelationships of Law and Social Science, in LAw AND THE Social Role of ScIENCE 108 (H. Jones ed. 1968) (discussing value of social science in law); Nagel, Law and the Social Sciences: What Can Social Science Contribute? 51 A.B.A.J. 356 (1965) (same). 
limits of social science. ${ }^{22}$ They can maintain ongoing efforts to monitor organizational behavior by issuing "structural" injunctions, ${ }^{23}$ consisting of a series of supplemental decrees. Finally, in the implementation process, courts can employ special masters, ${ }^{24}$ lay committees, ${ }^{25}$ and other enforcement panels. ${ }^{26}$ By using these varied techniques, the judiciary can collect the information needed to design and execute relief.27

Although critics are correct in noting that agencies will often oppose a court's attempts to change the institutions' policies, ${ }^{28}$ these observers fail to recognize that in some circumstances bureaucrats may willingly favor judicial intervention. The court's intervention might secure a level of funding that the bureaucrats would not have obtained through the normal political process. ${ }^{29}$ Furthermore, in situations of internal

22. See Yudoff, School Desegregation: Legal Realism, Reasoned Elaboration, and Social Science Research in the Supreme Court, 62 LAw \& ConTEMP. Prob. (No. 4) 57, 108 (1978) (social science has not been decisive in school desegregation cases because courts recognize inability to provide unambiguous answers). On the limits to the objective uses of social science generally in matters with political ramifications, see Frankel, $T$ he Autonomy of the Social Sciences, in Controversies and Decisions 9, 29 (G. Frankel ed. 1976); Wirth, Preface to K. Mannheis, Ideology and Utopia at xvii (1936).

23. See O. Fiss, The Civil Righrs InJunction 36-37 (1978) (uses of structural injunction in changing organizational behavior).

24. See, e.g., Chicago Hous. Auth. v. Austin, 511 F.2d 82 (7th Cir. 1975) (special master used in implementing housing discrimination decree); Hamilton v. Landrieu, 351 F. Supp. 549 (E.D. La. 1972) (special master used to oversee correctional reform).

25. See, e.g., Calhoun v. Cook, 362 F. Supp. 1249, 1252 (N.D. Ga.) (per curiam), remanded, 487 F.2d 680 (5th Cir. 1973) (establishing Biracial Committee to oversee school desegregation remedy); Wyatt v. Stickney, 344 F. Supp. 373, 378 (M.D. Ala. 1972), aff'd in part, rev'd in part sub nom. Wyatt v. Aderholt, 503 F.2d 1305 (5th Cir. 1974) (establish. ing "human rights committees" to oversee mental health institutional reform).

26. See, e.g., New York State Ass'n for Retarded Children v. Carey, 393 F. Supp. 715, 717 (E.D.N.Y. 1975) (expert professional advisory board used in restructuring facility for retarded children). If dissatisfied with the implementation process, the court could resort to receivership, in which a court-selected official would take the place of the defendant officers for the purposes of administering the decree. See FED. R. Crv. P. 66 (federal courts can appoint receivers); Comment, Equitable Remedies: An Analysis of Judicial Utilization of Neoreceiverships to Implement Large-Scale Institutional Change, 1976 Wrs. L. REv. 1161 (studying receivers and other court-appointed officers).

27. See Note, Implementation Problems in Institutional Reform Litigation, 91 Harv. L. REv. 428, 435-62 (1977) (examining uses of devices in institutional reform).

28. See Morgan v. McDonough, 540 F.2d 527 (Ist Cir. 1976), cert. denied, 429 U.S. 1042 (1977) (resistance of school officials, administrators, and community to court decision in desegregation case led to school being placed in receivership); Roberts, The Extent of Federal Judicial Equitable Power: Receivership of South Boston High School, 12 New ENG. L. REv. 55 (1976) (discussing South Boston receivership).

29. See Milliken v. Bradley, 433 U.S. 267, 293 (1977) (Powell, J., concurring) (school board and plaintiffs, formerly antagonists, "joined forces apparently for the purpose of extracting funds from the state treasury"); Note, The Wyatt Case: Implementation of $a$ Judicial Decree Ordering Institutional Change, 84 YALE, L.J. 1338, 1367-68 (1975) (head of mental health system looked upon decree as method of obtaining increased financial support from governor and state legislature).

It should be noted that court action might not yield the desired effect. The judiciary cannot directly require the appropriation of funds. See Frug, supra note 9, at 770. Thus, if a funding body chooses not to increase an agency's budget, then the bureaucracy would 
bureaucratic disagreement, some factions may welcome judicial intercession in support of their position..$^{30}$ Moreover, while elected executives and legislators might more closely monitor the preferences of the public, judges sometimes may be better able to fashion a rational plan because they are relatively free of the pressures of lobbyists, bureaucracies, and interest groups. ${ }^{31}$

Courts, in sum, can create the apparatuses needed to make and monitor decisions. But such a finding can hardly end an examination of judicial capacity to remake the processes and policies of public bureaucracies. The locus of discussion in much of the literaturewhether courts have the equipment to intervene effectively-is misplaced. Machinery designed to collect data is of minimal assistance in interpreting information. Nor can it aid a judge in determining what factors should be considered in choosing a remedy. In short, formal machinery by itself does not ensure that the judiciary will fashion workable relief, and therefore should not be of principal concern. Rather, the focus should be on the delineation of criteria by which a judge can create an appropriate remedy.

\section{Guiding Judicial Intervention: The Uses of Organization Theory}

The implementation of new policies and procedures often involves changing the behavior of public bureaucracies;32 a remedial plan will be successful largely to the extent to which the court appreciates the

have to restructure its own priorities. In order to raise the money needed to implement the court's decree, it might have to lower the level of funding of other programs. See Milliken v. Bradley, 433 U.S. 267, 293-95 (1977) (Powell, J., concurring) (state board resisted assuming city's portion of excess costs resulting from court-ordered remedial plan); D. Horowirz, supra note 2, at 258-59 (court ordered government and school system to provide education for emotionally disturbed children, but city refused to acknowledge financial responsibility). In some situations, however, a court may be able to in effect compel the funding unit to appropriate funds. See Wyatt v. Aderholt, 503 F.2d 1305, 1314-15 (5th Cir. 1974) (implying that if state did not comply with decree, court might choose master to sell state lands for purpose of securing needed funds).

30. Cf. H. Heclo, a Government of Strangers: Executive Politics in Washington 154-90 (1977) (divergence in perspectives may exist between political executives, who serve at pleasure of elected officials, and careerists, whose tenure is generally assured); Neustadt, Politicians and Bureaucrats, in The Congress AND AMERICA's Future 118 (D. Truman ed. 1973) (same).

31. See Chayes, supra note 2, at 1307-08 (noting such advantages). But see Glazer, supra note 2 , at $70-71$ (questioning Chayes's view).

32. "Bureaucracy" is defined as a large organization (a consciously coordinated system of activities among two or more persons) in which the responsibility for achieving this coordination is divided among several appointed officials. C. Barnarp, The Functions of The Executive 73 (1938); J. Wilson, The Investicators 217 n.2 (1978). Bureaucracy was the subject of Max Weber's classic analysis. M. Weber, The Theory of Social AND Economic Organization 329-40 (T. Parsons ed. 1947). 
particular characteristics of the organization it is scrutinizing. A remedial approach that works in one context may fail in another. Hence, the critical task for those interested in effective intervention is to alert the judge to the complexities of restructuring bureaucracies. ${ }^{33}$ Organization theory can provide courts with the necessary guidance to understand how bureaucracies function and thus to reshape institutions effectively.

\section{A. An Organization Theory Framework}

Organization theory establishes that in order to understand the behavior of public bureaucracies, it is necessary to examine the interaction of internal factors and external forces. ${ }^{34}$ The theory identifies those internal and external factors that can affect the policies and even the survival of the bureaucracy. By utilizing these concepts to ascertain if means are available and usable to achieve the stated end, a judge can determine whether a proposed remedy is likely to be effective. ${ }^{35}$ Moreover, he can estimate the difficulties that would be incurred in implementing each option, and can then design a remedy tailored to the situation. ${ }^{30}$

\section{Internal Organizational Factors}

Organization theory examines five basic internal factors: mission, goals, tasks, power structure, and autonomy.

33. Cf. H. Kaufman, The Limits of Organizational Change 5-92 (1971) (examining why organizations difficult to change); Wilson, The Bureaucracy Problem, 6 PUB. INTEREsT 6.9 (1967) (discussing problems bureaucracies face).

34. Organization theory from the political scientist's perspective focuses on empirical inquiry, that is, on how organizations do behave, not on how they should behave, and holds that to understand outcomes it is necessary to study a multiplicity of factors, internal and external. For model studies of organizational behavior, see H. KAUFMAN, THE FoREST RANGer (1960) (forest rangers in forest service); J. WiLson, supra note 32 (managing FBI and narcotics agents). The analysis presented here does not seek to present a comprehensive survey of organization theory in all its complexity, but endeavors to familiarize the reader with basic concepts.

35. See H. Simon, Administrative Behavior 61 (3d ed. 1973) (administrative decision correct if it selects appropriate means to reach designated ends).

36. Remedial design may involve major changes or innovations within an organization. Innovation in Wilson's view proceeds in three stages: the conception of the change, the proposing of the change, and the adoption and implementation of the change. See Wilson, Innovation in Organization: Notes Towards $A$ Theory, in Approaches to OrGAnizational Design 195, 198 (J. Thompson ed. 1964). See generally G. Downs, Bureaucracy, Innovation ANd Public Policy (1976) (innovation of policies in bureaucracy). On the implementation stage, see, e.g., E. BARDAch, The Implementation GaMe (1977); E. HARGROVE, The MIssing LINK (1975) (discussing need for greater attention to problems of implementation); J. Pressman \& A. Wildavsky, Implementation (1973) (case study of implementation of employment program). 
a. Mission. Typically, an organization seeks to instill a sense of "mission" in its members. An organizational mission is not merely the formal goal of the organization, but a "distinctive and valued set of behaviors," 37 a shared feeling among organization personnel about the nature, feasibility, and importance of the organization's tasks. ${ }^{38}$ In order to develop this feeling of mission or distinctive competence, bureaucracies must cultivate an organizational ethos, an attitude about the value of the tasks and the work of the organization. ${ }^{30}$ When a strong sense of mission exists, the difficulties in securing the necessary level of cooperative effort decrease; ${ }^{40}$ upper-level administrators will be able to secure cooperation from below and need not closely monitor employees or dispense instructions to the degree necessary when a sense of mission is lacking. ${ }^{41}$

b. Goals. Goals are images of desirable future states of affairs. ${ }^{42}$ Unlike mission, which relates to the overall ethos of the organization, goals are the specific objectives toward which an agency's behavior is directed. An organizational goal is "utopian" if it specifies a desired state that is impossible to reach, ${ }^{43}$ and "operational" if it can be achieved. ${ }^{44}$ Specific or detailed goals, moreover, may be derived from generally stated ones: the goal that is thus derived is termed a sub-goal. ${ }^{45}$ In addition, individuals within the organization may have personal goals relating to their aspirations in terms of income, power, position, or prestige. ${ }^{46}$

37. J. Wirson, supra note 32 , at 14 (emphasis in original).

38. See P. Selzick, Leadership and Administration 17, $42-56$ (1957) (developing concept of mission); cf. M. Halperin, Bureaucratic Politics and Foreign Policy 26-40 (1974) (examining mission of military organizations).

39. See P. SeLzNICK, supra note 38 , at $42-56$.

40. See J. Wirson, supra note 32 , at 13 (belief in bureaucracy's mission facilitates organizational loyalty).

41. $I d$.

42. This is a standard definition that usually begins a discussion of goals. See, e.g., F. Kast \& J. Rosenzweig, Organization and Management 156 (1974); J. Wilson, Political. Organizations 46 (1973). The manner in which goals are defined and used has been a subject of much discussion. See, e.g., R. Cyert \& J. March, A Behavioral Theory of THE FIRM 26-43 (1963) (goals are set as result of bargaining among coalitions of various participants); H. SimoN, supra note 35, at 262 (organizational goal defined in terms of constraints or requirements that organization must meet); Perrow, The Analysis of Goals in Complex Organizations, 26 AM. Soc. REv. 854 (1961) (distinguishing between official organizational goals and those that actually characterize institution's behavior).

43. For example, absolute elimination of crime is a "utopian" goal.

44. That is, one can make an unambiguous judgment that the desired state of affairs has come into being. J. March \& H. Simon, ORganizations 155 (1958).

45. See id. at 190-93; H. SIMON, supra note 35 , at 62-66 (on relationship between means and ends).

46. See A. Downs, Inside BurEaucracy 79-111 (1967) (examining milieu, motives, and goals of various kinds of bureaucrats). Personal goals are not necessarily compatible with organizational goals. See H. SiMon, supra note 35, at 65-66. 
c. Power Structure. Some actors in an organization typically exert more influence on decisions than do others. ${ }^{47}$ On any particular issue, the influence of a participant on organizational decisions and outcomes is dependent on a number of factors: formal position in the hierarchy, involvement in upper-level decisionmaking, access to information needed to identify options, control over resources needed to implement decisions, and personal capacity to persuade others. ${ }^{48}$

d. Tasks. Tasks-the work of the organization-may be regarded as being either programmed or nonroutine. ${ }^{49}$ Programmed tasks are performed on a routine, predetermined basis. ${ }^{50}$ Because such tasks involve little discretion, they can be controlled by providing a detailed set of specifications or "program" describing how the tasks are to be performed..$^{51}$ Nonroutine tasks, on the other hand, involve only a minimal level of prescribed repetitive operations. ${ }^{52}$ Such tasks are often complicated and vary with the changing environment. Employees performing such tasks are vested with considerable discretion. As the number of nonroutine tasks increases, the organization's need to monitor the behavior of those vested with discretion becomes greater. Thus, this development is typically accompanied by the addition of supervisory levels and the creation of specialized units. ${ }^{53}$

e. Autonomy Versus Coordination. Organizations generally seek an independent sphere of action, or "autonomy." ${ }^{4}$ A bureaucracy's leadership typically believes that the organization will perform best when free from interference by others who have little knowledge or understanding of its activities. When a major policy area cuts across many departments and agencies, the chief executive may seek to coordinate the activities of those organizations in order to foster administrative

47. A growing literature has arisen about what Graham Allison has termed the "bureaucratic politics" model. See G. Alison, Essence of Decision: Explaining the Cuban Missile Crisis 162 (1971). The model views outcomes as the result of bargaining among many actors who pull and haul with the power at their discretion for ends that will further their conception of national, organizational, and personal interests. See, e.g., G. Allison \& P. Szanton, Remaking Foreign Policy: The Organizational Connection (1976); M. Halperin, supra note 38; R. Neustadt, Presidential Power (1976 ed.).

48. See G. Allison, supra note 47 , at $168-69$.

49. The "programmed" task notion was developed by March and Simon. See J. March

\& H. Simon, supra note 44 , at 142-44.

50. Id.

51. Wilson, supra note 36 , at $\mathbf{1 9 8 - 9 9}$.

52. Id. at 198 .

53. Id. at 199.

54. See, e.g., M. Halperin, supra note 38, at 51-54 (military organizations' desire for freedom of movement); J. WILson, supra note 32, at 161, 164 (law enforcement officers' concern for autonomy); cf. M. Crozier, The Bureaucratic Phenomenon 196 (1964) (bureaucracies concerned with power and uncertainty). 
coherence and eliminate overlapping programs. ${ }^{55}$ The desire for institutional autonomy, however, generally leads an organization to resist efforts to coordinate its behavior with that of another organization. ${ }^{50}$ Coordination is particularly difficult when the organizations have diverging conceptions of their missions and goals, or when they disagree about the best way to achieve a goal. ${ }^{.7}$

\section{External Forces}

Forces external to an organization can limit its freedom of action or induce it to pursue certain programs..$^{58} \mathrm{~A}$ legislature, for example, can enact laws that shift the policy course of a public agency ${ }^{50}$ It can confer or withdraw power, or change the agency's funding, thereby influencing the kinds of programs that the agency can undertake and the intensity with which it can pursue them. ${ }^{60}$ Furthermore, a public bureaucracy often needs cooperation from nongovernmental actors beyond its control if it is to succeed in its mission. ${ }^{01}$

55. See H. Seidman, Pourtics, Position ANd Power 164 (1970). "Coordination" might more properly be considered when examining external factors. However, because bureaucracy's desire for autonomy leads it to resist coordination, it is logical to examine the coordination concept here, together with that of autonomy.

56. J. WiLson, supra note 32 , at 165 . For studies that discuss the problems of coordination, see N. Caiden \& A. Wildavsky, Planning and Budgeting in Poor Countries 277-79 (1974) (complexities of joint action); J. Pressman, Federal Programs and City Politics (1975) (dynamics of aid process in Oakland); H. SEIDMan, supra note 55, at 164-94 (difficulties in coordinating federal agencies); J. SunDouist, Making FEDERALisM WORK 13 (1969) (coordination problems in intergovernmental relations).

57. See J. Pressman, supra note 56, at 10. Even when bureaucracies may initially reach a policy agreement, that shared view may collapse during the implementation process. See M. Derthick, New Towns In-Town: Why a Federal Program failed (1972).

58. See M. Bernstein, The Job of the Federal Executive 10-136 (1958) (how certain external forces affect job of federal executive); J. WiLson, supra note 32, at 164 .

59. See R. Fenno, The Power of the Purse 216-314, 564-615 (1966) (impact of appropriations committees on agencies); M. Kirst, Government Without Passing Laws 64-118 (1969) (nonstatutory means of legislature to influence executive by controlling agency budgets).

60. Even before a public bureaucracy submits its budget to the legislature, it may have to secure approval of its funding request from a budget agency that is charged with overseeing the programs of all government organizations to assure that they are in accord with the chief executive's basic policies. The budget authority can also affect the priorities of bureaucracies by passing judgment upon the way in which each agency allocates resources among programs within its domain. See A. Wildavskx, The Politics of THE BuDgetary Process 1-126 (2d ed. 1974) (effect of budget bureau on agency funding); Heclo, $O M B$ and the Presidency-the Problem of "Neutral Competence," 38 PuB. INTEREsT 80 (1975) (impact of OMB on bureaucracies' programs).

61. For instance, the efficacy of a board of education's desegregation program may depend on its ability to persuade parents not to withdraw their children from the public school system. See G. Orfield, The Reconstruction of Southern Education (1969) (mechanics of school desegregation). 


\section{B. Organization Theory and Court Intervention}

Organization theory suggests that a decisionmaker, in fashioning a remedial plan, should "backward map"-that is, focus on what must be done in the final stages to resolve the problem as defined, determine whether the means are available to achieve the desired end, and then ascertain whether he is free to use those means. ${ }^{62}$ By studying how a proposed plan affects the internal and external forces that organization theory identifies, the decisionmaker should be able to forecast many of the difficulties in the implementation process. Moreover, in designing and implementing relief, he should make use of feedback mechanisms ${ }^{\mathrm{B}}$-devices to secure information-so that he might assess the effectiveness of his order, spot problems, and, if necessary, modify his directives in the face of changing circumstances.

\section{Internal Factors}

a. Mission and Goals. In applying organization theory, a court will recognize that change will be difficult in an organization that has successfully instilled a sense of mission; those who believe in the bureaucracy's mission are likely to resist judicial efforts to alter it. Indeed, professionals, whose behavior and policy perspectives are constrained by norms derived from external reference groups that allocate rewards such as advancement and esteem, are particularly likely to resist attempts to reorient the organization in a way that conflicts with their conception of what the bureaucracy should be doing. ${ }^{64}$ Moreover, professionals and nonprofessionals alike may obstruct efforts to change the organization's mission and goals if they perceive that their personal goals will be threatened.

In addition, a court should realize that it will more likely achieve its goals if it defines those ends unambiguously so that the relevant actors will clearly understand what is required of them. ${ }^{65}$ A judge

62. See R. NEUSTADT, supra note 47 , at 41.42 (discussing backward mapping); Allison, Implementation Analysis: The Missing Chapter in Conventional Analysis: $A$ Teaching Exercise, in Benefit-Cost \& Policy ANALYsis: 1974 at 369 (R. Zeckhauser ed.) (discussing importance of such implementation analysis).

63. See H. Kaufaran, Administrative Feedback (1973) (studying administrative feedback in nine federal bureaus); $T$. Whisler, Information Technology and Organizational Change (1970) (feedback control and application to management).

64. See P. Blau \& W. Scott, Formal Organizations 60-74, 242-47 (1962) (discussing how professionalism affects behavior of personnel); R. KatzManN, Regulatory Bureaucracy $36-57,76-86$ (1980) (examining how differing professional norms of lawyers and economists influence behavior).

65. If the goal is stated too generally, then parties with clashing views could thwart the implementation process. An example from urban policy serves as an apt illustration. In 
should make certain that the proposed remedy provides the technology for attaining those goals.

b. Power Structure. In order to minimize the difficulties involved in changing mission and goals, the judiciary must analyze the agency's power structure. ${ }^{66}$ It should identify those actors who can influence outcomes and determine which of those are likely to support judicial intervention. In fashioning a decree, the court should seek to give a leadership role to those elements that are most likely to comply with the judge's order. In cases in which it is feasible and necessary, the court should reorganize the existing structure so as to increase the power of sympathetic forces in the decisionmaking process.

c. Tasks. The success of judicial intervention depends to some extent on the nature of the tasks it seeks to affect; organization theory can help the court identify those tasks and problems. Routine tasks are relatively easy to change because it is necessary only to alter the program. Changing nonroutine tasks, however, complicates implementation of a plan: the court must establish monitoring devices to acquire performance data and then must react to that information. Moreover, changing tasks is even more difficult when the reward system is closely intertwined with task performance, ${ }^{67}$ that is, when employees accustomed to being rewarded for performing certain tasks have those tasks changed as a result of court action. Courts must induce organizational actors to perform the tasks necessary for compliance with the court order. Usually, judges will be most effective when the actors perceive that compliance will not diminish their professional rewards. ${ }^{88}$

d. Autonomy and Coordination. The court must be prepared to meet resistance if it seeks to coordinate the behavior of bureaucracies that are fearful of losing autonomy. These difficulties will increase if the bureaucracies disagree about goals or the way in which goals should

urban housing policy, the generally stated goal may be the "revitalization of slum areas." From this goal, no single operational sub-goal can be derived. It may be that the revitalization of slum areas could be achieved by increasing the political power of urban poor through expanded community action programs; alternatively, it may be that the goal could be attained by bolstering local mayors (perhaps by making more federal funds available to city halls). These operational goals conflict. Local mayors are likely to view expanded community action programs as threats to their own power. Community-based groups are likely to challenge city hall's authority. In the end, the conflict may actually frustrate the realization of the general goal. Cf. Brown, The Scope and Limits of Equality as a Normative Guide to Federal Health Policy, 26 PuB. PoL'Y 481, 488-96 (1976) (examining how problem definition affects policy conception and implementation).

66. See C. Diver, The Judge as Political Powerbroker: Superintending Structural Change in Public Institutions, 65 VA. L. REv. 43 (1979) (role of judge as powerbroker).

67. See Wilson, supra note 36 , at 200 .

68. Cf. Clark \& Wilson, Incentive Systems: A Theory of Organizations, 6 AD. ScI. $Q$. 129-66 (1961) (problems of organizational maintenance and distribution of incentives). 
be achieved. In such circumstances, the court must invest its resources in an attempt to forge cooperative activity among the relevant actors.

\section{External Factors}

Organization theory further instructs courts to appreciate that securing the responsiveness of actors external to the agency will be especially difficult when they themselves are not subject to the suit. Simply stated, judges cannot directly compel such outside agents. ${ }^{09}$ For instance, the judiciary cannot order a legislature to appropriate funds, nor may it prevent parents, dissatisfied with a school desegregation order, from withdrawing their children from public school and enrolling them in private institutions. ${ }^{70}$ Thus external forces over which a court may have little control can severely weaken a remedy. In situations in which the court must devise a remedy whose success depends upon the cooperation of external actors, organization theory suggests that courts engage those elements in the decisionmaking process and convince them of the high costs of noncompliance.

\section{III! Restructuring Institutions: The Case of Hart v. Community School Board}

The value of organization theory as a guide for judicial intervention can be demonstrated by examining Hart v. Community School Board, ${ }^{71}$ a case in which a federal district judge confronted the problem of fashioning an effective decree that changed existing organizational arrangements. Judge Jack Weinstein sought to restructure an educational institution, Mark Twain Junior High School, for the purpose of achieving racial integration. The case highlights the importance of understanding the character of organizations in designing structural remedies; had the court approached the remedial problem in the sys-

69. Cf. T. Becker \& M. Feeley, The Impact of Supreme Court Decisions (2d ed. 1973) (case studies showing in part dependence of courts on good faith of general public and officials in securing compliance). Because private bureaucracies, unlike public organizations, generally control factors of production, it may be easier for courts to restructure them. See generally Note, Structural Crime and Institutional Rehabilitation: A New Approach to Corporate Sentencing, 89 YALE L.J. 353 (1979) (discussing restructuring of corporations to inhibit institutional crime).

70. Cf. A. Hirschman, Exit, Voice and Loyalty 51-52 (1970) (parents can express unhappiness through "exit," that is, by leaving public school system).

71. 383 F. Supp. 699 (E.D.N.Y.), supplemented, 383 F. Supp. 769 (E.D.N.Y. 1974), aff'd, 512 F.2d 37 (2d Cir. 1975). The author wishes to express his appreciation to James Meyerson of the NAACP, who granted access to virtually all relevant documents. For a thorough description of the case, see Fishman, The Limits of Remedial Power, in THE LIMITS OF Justice 115 (H. Kalodner \& J. Fishman eds. 1978). 
tematic way that organization theory provides, it would more quickly have become conscious of the limits and opportunities of the possible options.

\section{A. The Problems Confronting the Court in the Hart Case}

Mark Twain Junior High School Number 239, located in Brooklyn's Coney Island, had become racially segregated by $1973 .^{72}$ Despite complaints about the problem from the parents of Mark Twain children and some local educators, ${ }^{73}$ the communicy school board ${ }^{74}$ refused to make changes in the existing order. ${ }^{75}$ The local school board was also

72. 383 F. Supp. at 711. The total enrollment had declined from 1933 students in 1962 to 713 ; the minority population had risen from about $19 \%$ in 1962 to $81 \%$. Id. Of the minority population, in 1973 , blacks accounted for about $43.3 \%$ of the student body and Hispanics for about $38.6 \%$. Id. In the community school district where Mark Twain was located, however, the minority population in 1973 was $17 \%$ of the total resident enrollment at the intermediate and junior high school levels. Id. at 712.

The problems of Mark Twain-racial segregation and underutilization-were attributable to a number of factors, but many resulted from the government's approach to housing and urban revitalization problems. See id. at 721-23. By 1974, the percentage of white children in New York City Housing Authority projects was approximately $18 \%$ and only $19.5 \%$ in state-supported Urban Development Corporation projects. Report of the Special Master: Part II-Physical and Human Renewal, at 2-11 [hereinafter cited as Special Master Report II] (on file with Yale Law Journal). The racial composition of area schoolsMark Twain Junior High School being one of the local educational institutions-mirrored that found in the housing projects.

Moreover, in large measure, the problems of Mark Twain could be traced to the actions and inaction of the local school board (Community School Board Number 21) and the reluctance of the Central Board of Education officials to intervene to rectify conditions. In various ways, the local board sharply reduced the white population of Mark Twain. See 383 F. Supp. at 715-19. For example, it changed the zoning patterns of two elementary schools with predominately white student populations such that pupils who formerly would have attended Mark Twain upon graduating from the sixth grade class were sent to other junior high schools. Id. The school board reduced the student enrollment at Mark Twain still further when it converted a recently constructed elementary facility into an intermediate school (with grades seven and eight) and then proceeded to populate it with predominantly white middle-income students whose neighborhoods were previously part of the Mark Twain zone. Id.

73. See 383 F. Supp. at 717; Trial Testimony of Doris Chitaro, reprinted in Appendix to Appellant's Brief, Docket No. 73-2990 at 23-26 [hereinafter cited as Appendix I].

74. Under the terms of a 1969 act to decentralize the New York City school system, the school districts are guided by elected community school boards (the "local boards") Senior high schools are still under the direct supervision of the central board of education (the "Central Board"), which is headed by a chancellor. The local boards make policy for the elementary and junior high schools. However, the Central Board reviews local board decisions with respect to zoning and integration matters; if the local board's decision runs counter to the policies of the Central Board, then the Central Board can order the local board to modify its decision. See Trial Testimony of Irving Anker, reprinted in Appendix I, supra note 73, at 1110-18.

75. The board decided upon this course after conducting a hearing at which parents vehemently opposed rezoning plans, arguing that Mark Twain was an educationally in. ferior institution, and that their children's safety would be endangered if they were sent to Mark Twain. 383 F. Supp. at 717. 
unresponsive to the order of the Chancellor of the New York City Board of Education ${ }^{70}$ to redress the racial imbalance; when the Chancellor did nothing to secure compliance, ${ }^{77}$ several white residents began a lawsuit. ${ }^{78}$

Following lengthy trial proceedings, ${ }^{79}$ including expert testimony, ${ }^{80}$ on-site inspections, ${ }^{81}$ and considerable off-the-bench research, ${ }^{82}$ the court, in its liability decision of January 28,1974 , held both the local school board and the Chancellor in violation of the equal protection clause of the Constitution. ${ }^{83}$ The court's order affected a wide range of

76. He issued his directives only after an appeal had been lodged with the state commissioner of education. Id. at 717 .

77. In response to then Chancellor Harvey Scribner's first directive in September 1971, the local board adopted a free-choice plan, but not a single white student enrolled at Mark Twain pursuant to the plan despite improvements made in the school's facilities and programs. Id. at 718. Scribner rejected the plan in April 1972 and directed that the board adopt a plan that would assure that by September 1974 the percentage of minority students would not vary from the districtwide average by more than $10 \%$. The local board refused to comply; on July 5, 1972, Scribner issued a new and milder directive. The local board rejected that as well and Scribner did nothing to enforce it. Id. at 717-20; see Trial Testimony of Irving Anker, reprinted in Appendix I, supra note 73, at 1121-26; Trial Testimony of Allen Zelon, reprinted in Appendix to Appellant's Brief, Docket No. 74-2076, at 674-89 [hereinafter cited as Appendix II].

78. The NAACP-sponsored suit, a class action on behalf of the children attending Mark Twain, was filed on August 4, 1972, and alleged that the local board and the chancellor were maintaining the school as an unconstitutionally racially segregated and underutilized school. See Plaintiffs' Complaint, reprinted in Appendix I, supra note 73, at $2769-89$.

79. Trial proceedings began on January 2, 1973 and final oral argument on the liability questions was completed on December 19, 1973. Plaintiffs sought to show that segregation at Mark Twain was due to the actions and inaction of school officials. See 383 F. Supp. at 715-21. While virtually conceding that the school was segregated, the defendants responded that they had never intended to bring about the racial imbalance at Mark Twain. See Answer of Defendant Community School Board and Officials thereof, reprinted in Appendix I, supra note 73, at 2793-96; Answer of Defendant Chancellor, reprinted in id., at $2782-93$. School officials maintained that their fear of escalating white flight militated against the use of more stringent measures to integrate the school. See Testimony of Irving Anker, reprinted in id. at 1139-40, 1142. In the alternative, the local board claimed that if segregation existed, it resulted from housing policies, promulgated by other governmental agencies. See Answer of Defendant Community School Board and Officials thereof, supra, at 2793.

80. See Testimony of Nathan Glazer, reprinted in Appendix I, supra note 73, at 2177237 (expert testimony called by defendant school board); Testimony of Dan Dodson, reprinted in id. at 456.839 (testimony by plaintiffs' expert).

81. The judge toured the school and the Coney Island area. 383 F. Supp. at 710; Remarks of Judge Weinstein, reprinted in Appendix I, supra note 73, at 1712.

82. See 383 F. Supp. at 743.47 (citing wide range of social science sources). The judge's willingness to engage in off-the-bench research was indicated by his response to Attorney James Meyerson's request to read an article from the Harvard EDucational Review: "I will read it, I have a lot of other things in the case and I might as well read that, too." Remarks of Judge Weinstein, reprinted in Appendix II, supra note 77, at 916.

83. 383 F. Supp. at 707, 716, 721. The Court declared:

[A]s in the case of so many tragedies of our times, the many people of good will and

fine intentions were overwhelmed by social tides beyond their individual control. 
parties. In an effort to achieve a comprehensive solution, ${ }^{84}$ the judge directed virtually all agencies that had even the slightest relation to education policy-schools, ${ }^{35}$ housing, ${ }^{80}$ transit, $^{87}$ park, ${ }^{88}$ and police authorities ${ }^{89}$-to submit plans on March 1, 1974 that would be operative in September $1974 . .^{\circ 0}$ In particular, Judge Weinstein seemed committed to the view that a major restructuring of housing and other urban policies in the Coney Island area was essential to achieve the desegregation objectives; it was thus clear that the responses of the housing agencies would be of central importance.

Plaintiffs submitted six possible plans, ${ }^{91}$ but stated a preference for a busing plan that would create virtually equal percentages of minority enrollment in every junior high and intermediate school in the district. ${ }^{22}$ The Chancellor's proposals also entailed busing. ${ }^{93}$ The local school board, however, proposed that Mark Twain become a magnet school-a facility for specially gifted children drawn from the entire

And the bureaucracies, instead of imaginatively drawing together all agencies of the government, separately applied the logic of consistency to deaden the spirit of resistance, making segregation inevitable instead of only highly probable.

Id. at 707.

84. Id. at 753-54. The defendant school board impleaded those agencies that it held responsible for the segregation-the mayor, the City of New York, federal, state, and municipal housing authorities and officials. See Answer of Defendant Community School Board and Officials thereof, reprinted in Appendix I, supra note 73, at 2794. The community school board requested that the court order desegregation of public housing and direct that the federal and state housing authorities be forbidden to authorize new loans and grants to New York City until they had eliminated policies that resulted in segregation. $I d$. at 2795-96.

85. Education authorities were to develop a plan so that Mark Twain's minority student population would not deviate by more than $10 \%$ from the districtwide average of nonwhite pupils in junior high and intermediate schools. $383 \mathrm{~F}$. Supp. at 756.

86. Id. at 757. Housing authorities of the city, state, and federal governments were ordered to submit a joint plan that would "undo the racial imbalance in publicly-supported housing in Coney Island." Id.

87. The Metropolitan Transit Authority was ordered to rearrange bus schedules to provide service to Mark Twain. Id.

88. The Park Department was to join in planning as "Mark Twain makes heavy use of Park Department facilities." Id. at 758.

89. The police commissioner was to "present a plan for adequate protection of children in the vicinity of the school." Id.

90. Id. at 756. The court expected these many agencies to work together, declaring: "I am not going to permit one agency to pass the buck to another and say that we cannot do it." Transcript of Judge Weinstein's remarks, reprinted in Appendix II, supra note 77 , at 1363 .

91. Memorandum from Dan W. Dodson to NAACP Special Contribution Fund (Feb. 22, 1974) (on file with Yale Law Journal).

92. 383 F. Supp. at 771 .

93. Report of the Chancellor Pursuant to the Opinion of the Court in Hart v. Community School District 21, March 1, 1974, at 9 (on file with Yale Law Journal). In this report, the Chancellor sharply criticized the court's order, charged it was "counterproductive," $i d$. at 8 , and argued that a shift in housing policy was the key to integration, id. at 10 . 
district.94 Implementation of this proposal would not require busing, an option opposed by most of the elected, and hence, politically sensitive, school board members. ${ }^{95}$ The plans of the Police Department, New York City Parks, Recreation and Cultural Affairs Department, and Transit Authority varied in degrees of responsiveness. ${ }^{96}$ In general, officials of the city, state, and federal agencies indicated in various ways that their organizations could do little in the near future to change housing conditions in Coney Island..$^{97}$

Realizing how difficult it would be to develop a plan involving all of the affected agencies, ${ }^{98}$ the court concluded that it had to create some means to coordinate the activities of the many bureaucracies and to devise and then implement a remedial program. ${ }^{99}$ For those purposes, the court appointed a special master ${ }^{100}$ who was to consult informally with the parties and outside experts, develop a comprehensive plan, and, if possible, gain the parties' consent to his blueprint. ${ }^{101}$ After

94. 383 F. Supp. at 759-60. Students would be drawn only from the district, and would be specifically admitted to accelerated and enriched programs on the basis of standardized examinations. Mark Twain would adhere to the approximate ratio of $70 \%$ white, $30 \%$ minority. The school would gradually phase in its operation. Parents would have the right to withdraw their children from Mark Twain and have them returned to their zoned school immediately and for any reason. See 383 F. Supp. at 711; Testimony of Allen Zelon, March 6, 1974, at 332-416 (on file with Yale Law Journal). Throughout the balance of the case, the school board supported the magnet school concept as being the most palatable and workable solution.

95. See Report of the Special Master: Part I-the School PIan, at 4, 54 (on file with Yale Law Journal) [hereinafter cited as Special Master's Report I]; Interview with James Meyerson, NAACP attorney, June 10, 1978 (notes on file with Yale Law Journal).

96. The Police Department provided a "plan to protect children coming and going to school and against intruders." 383 F. Supp. at 759. The Parks, Recreation and Cultural Affairs Administration announced that it would rehabilitate bathroom facilities in the park next to the school. Id. The court deemed this measure insufficient in view of the park's unsafe and deteriorating conditions. $I d$. The Transit Authority provided what the court termed "helpful" data about transportation routes. Id.

97. See, e.g., id. at 760 (New York City Housing and Urban Development Administration submitted variety of proposals; none "prepared specifically to meet the issues raised in [the] lawsuit"); Testimony of S.W. Green, reprinted in Appendix II, supra note 77, at 1509-10 (Regional Administrator of Department of Housing and Urban Development stated his agency was frustrated by Office of Management and Budget's "reserving" of hundreds of millions of dollars); N.Y. Times, March 2, 1974, $\S 1$, at 34, cols. 1-2 (Lee Goodwin, Commissioner of New York State Division of Housing and Community Renewal characterized agency as "constricted by crippling inflation"); Letter of Edward Logue, President of State Urban Development Corporation, to Judge Weinstein (March 1, 1974) ("After meetings among the representatives [of the many agencies at the state, local and federal levels] no agreement has been reached.") (copy on file with Yale Law Journal).

98. As the varied responses clearly showed, the agencies operated on different levels of government and under different laws, regulations, and methods of financing. Accordingly, Judge Weinstein extended the effective date of the plan one year past the date initially set. 383 F. Supp. at 762.

99. Id.

100. Id.

101. Id. The master's plan was to be wide-ranging, "dealing not only with the elimination of segregation at the Mark Twain Junior High School but also with the housing, 
months of study, the special master recommended that the court adopt a modified version of the local board's magnet school proposal. ${ }^{102}$ Moreover, because the special master believed, as apparently did the judge, that the key to long-term racial integration would be effective housing and physical renewal in Coney Island, ${ }^{103}$ he proposed a housing plan designed to attract middle-income families to central Coney Island via lower rents, higher maximum income-eligibility requirements for public housing, and increased housing subsidies. ${ }^{104}$

The court held hearings on the special master's report that covered both the education and housing plans. The school board supported the special master's report, ${ }^{105}$ but the plaintiffs opposed the magnet remedy, contending that it would be inappropriate. ${ }^{106}$ Housing offi-

nonresidential development, community, social welfare, recreational, transportation and protective facilities within the Coney Island neighborhood necessary to provide a basis for effectively desegregating Mark Twain ...."Id. at 768. Curtis Berger, a Columbia Law School professor and an expert on the law of property, was appointed special master. Id. at 767. Berger spent three months gathering information about the housing and education problems in Coney Island. See Letter of Transmittal with Special Master's Report, Part II, at v (July 8, 1974) (on file with Yale Law Journal). For a personal view of the special master's tasks, see Berger, Away From the Court House and Into the Field: The Odyssey of a Special Master, 78 Corum. L. REv. 707 (1978).

102. Unlike the Board, he suggested that the school admit students who showed talent in typing, shorthand, music, athletics, art, wood and metal crafts. The Special Master urged that measures be taken to assure that the school be free of the segregative effects of tracking, lest the purpose of the enterprise be defeated. Special Master's Report I, supra note 95, at 4, 6, 17-19; Testimony of Curtis Berger, July 11, 1974, at 301, 304, 306 (on file with Yale Law Journal). With the support of the school board, the special master believed that this plan had the best chance of succeeding. Special Master's Report I, supra note 95 , at 9 . The alternative of busing could lead to white flight, Berger argued, thereby exacerbating the problems of racial imbalance. Id. at 54. Berger strategically combined his endorsement of the magnet school concept with a recommendation calling for implementation of the plaintiff' busing proposal if his own plan failed. Id. at 43,47 48. To make the magnet Mark Twain as attractive as possible, he further suggested that all schools but Mark Twain phase out special and enrichment programs. Testimony of Curtis Berger, reprinted in Appendix II, supra note 77, at 2275.

103. See Special Master Report II, supra note 72, at ii, 1. Upon surxeying existing housing policies, the special master concluded that "if the current trend continues, significant integration cannot occur." Id. at 23.

104. Id. at iii, 22-39. He urged adoption of a relocation plan that sensitively met the needs of site residents. Id. at iii. His report called for the replacement of existing substandard housing, home ownership, vigorous building code enforcement, and the construction of shopping centers and commercial areas. See $i d$.

105. Representatives of the local board, once skeptical about the court's efforts, were pleased that the special master had accepted the magnet school concept. See Testimony of Evelyn Acquila, local board member, reprinted in Appendix II, supra note 77, at 2288-316.

106. Critics of the education plan objected at the hearings that it would make Mark Twain a "special elitist school," Clark, Reactions to the Report of the Special Master (Curtis J. Berger), Part I: The School Plan, reprinted in Appendix II, supra note 77, at $306 c$, that it was a "blatantly racist solution to the problem," Memorandum from Dan Dodson to NAACP Special Contribution Fund Regarding Report to the Special Master (July 8,1974 ), reprinted in id., at 470 , in that minority youths would have to leave the community so that "favored whites," id. at 477 , could "voluntarily transfer" to Mark 
cials $^{107}$ and local residents ${ }^{108}$ vigorously criticized the housing blueprint. Ultimately, in its remedial order of July 26, 1974, the court adopted the local board's plan for a magnet facility, together with the

Twain, id. In response, Berger sought to show that the magnet plan when fully operative placed only a marginally greater burden on blacks, and that even under the Dodson plan (Model II), a substantial number of nonwhites in Coney Island would have to attend schools other than Mark Twain. In addition, he contended that his plan was more likely to achieve lasting integration than Dodson's Model II, which he believed would lead to white flight. Testimony of Curtis Berger, reprinted in id. at 2233-40, 2274-75.

107. City and state housing officials argued that Part II of the special master's report, the human and physical renewal study, was fraught with administrative nightmares that made it impractical. See Starr \& Zucotti, Response of Third-Party Defendant City of New York to Part II of the Report of the Special Master (July 23, 1974), reprinted in Appendix II, supra note 77, at 535-46. Relocation of 1,000 families in less than a year, they claimed, was virtually impossible. $I d$. at 544 . Moreover, because the plan would primarily benefit people not living in Coney Island, it posed important questions of equity and ran counter to the city's policy with regard to site residents. $I d$. at 537; see Testimony of Roger Starr, Administrator of Housing and Development Administration, reprinted in id., at 2452, 2491-92.

The costs to the city, New York City officials argued, could be limitless, and the state and federal governments should shoulder more responsibility. See Starr \& Zucotti, supra, at 537, 542; Testimony of Roger Starr, supra, at 2451-52. But the state objected that the special master's recommendations would be an "open-ended draft on the treasury of the State of New York." Objections to the Report of the Special Master Part II, "Physical and Human Renewal" (Third-Party State Defendants), reprinted in Appendix II, supra note 77, at $479 \mathrm{f}$.

For their part, federal authorities stated that they did not have the necessary funds and that in any case they were opposed to that part of the Berger plan that would have involved raising the maximum limits on the incomes of persons who could enjoy subsidies. See Testimony of S. William Green, regional administrator of HUD, reprinted in id., at 2323-25. Some housing officials, moreover, were skeptical about the special master's assumption that the "housing bargain" would induce white families to settle in Coney Island and to send their children to public schools if they did make the move. See Testimony of Roger Starr, supra, at $\mathbf{2 4 6 0 .}$

108. Undoubtedly, the most severe criticism of the Berger housing and renewal report came from a group of intervenors consisting of approximately 1,000 low-income black and Puerto Rican families who resided in the public housing projects in Coney Island. These families charged that a court order to repopulate the housing projects with white families might result in their displacement. These persons believed that none of the parties were representing their interests. The NAACP was concerned essentially with educational issues and therefore might not oppose an integrated housing approach that led to their uprooting. See Remarks of Nancy LeBlanc, lawyer for the intervenors, reprinted in Appendix II, supra note 77, at 1902. Judge Weinstein permitted those residents with children in the school system-that is, those who would be affected by both housing and school orders-to intervene. Others, affected only by the housing report, could file an amicus brief. Decision of Judge Weinstein at Hearing of June 14, 1974 , reprinted in id. at 1946-47.

The intervenors claimed that the Berger report was "inherently racist" and criticized the special master for "accepting" the proposition that the people of Coney Island "are part of the problem that has led to the segregation of Mark Twain." Objections to the Report of the Special Master, Part $I$ and II of the Intervenors, reprinted in id. at 480, 483. It is interesting to note, moreover, that the intervenors argued that "since the special master's proposal is so all encompassing . . . it would better be left to the normal political process for discussion, decision and implementation." Id. at 492. Thus, in this instance the poor embraced a rather conservative view of judicial power. $C f$. Bickel, supra note 5 , at 175 (complex problems best left to society to resolve out of its tradition). 
special master's suggestion that the new school be phased in gradually. ${ }^{109}$ 'The plaintiffs' busing proposal was held in reserve to be implemented if the magnet school failed. ${ }^{110}$ Although the court had spoken earlier of the need to coordinate the activities of housing, educational, and other agencies, ${ }^{111}$ the final order almost completely ignored the housing recommendations, except to request monthly progress reports from the parties about their urban revitalization efforts in Coney Island.112

Less than a month after the decree, the local board began to implement the magnet school plan with such diligence that the court and special master rarely intervened further. ${ }^{113}$ The local board undertook an intensive and wide-ranging public relations campaign to influence the attitudes of parents involved in the Mark Twain experiment. ${ }^{114}$ The magnet school opened in September 1975 and has met the court's required 70-30 majority-to-minority enrollment ratio. ${ }^{115}$ Applications in the years following the school's opening have exceeded the number of seats. ${ }^{116}$

109. 383 F. Supp. at 774 .

110. Id.

111. Id. at 762 .

112. Id. at 775. The court concluded that the "decretal tool is poorly designed for restructuring an entire community." Id. Within 14 months, the court relieved all parties of the obligation to file further reports, unless otherwise required. Weinstein, J., Memo and Order, Discontinuing Monthly Reports (Sept. 8, 1975) (on file with Yale Law Journal).

113. While in general agreement with the court's decision, the local board appealed the part that called for the utilization of the Dodson Plan as a stand-by, the section that mooted the third-party complaint, and the portion that held it liable for the segregation at Mark Twain. The plaintiffs appealed, and objected to the choice of the magnet school and to the change in the desegregation timetable from September 1974 to September 1975. The Second Circuit unanimously upheld the lower court's finding of de jure segregation and the proposed remedy. Hart v. Community School Board, 512 F.2d 37, 51, 54.55 (2d Cir. 1975).

114. See Letter of Allen H. Zelon, President of Community School Board 21 and Bartelo Peluso, Community Superintendent, to Parents (Jan. 23, 1975) (cover letter of brochure designed to attract applicants) (on file with Yale Law Journal).

115. See Junior High School Ethnic Distribution by Grade (May 22, 1978) (on file with Yale Law Journal). Concern that the school might become internally tracked according to race has, at least thus far, been unwarranted. See Letter and enclosure from Hyman Bravin, counsel to Community School Board 21, to James Meyerson, NAACP attorney (May 23, 1978) (data showing distribution of races within classes) (on file with Yale Law Journal).

116. Oelsner, New York's Best Public Schools Defy Racial Stereotyping, N.Y. Times, Jan. 23, 1978, \$ B, at 1 , col. 3. Commenting on the Mark Twain experiment, James Meyerson, the NAACP attorney in the case, reportedly stated that the school is "a magnificent example of what desegregation can do." Id. at 17, col. 2.

The accomplishment of the Mark Twain experiment should not be minimized; yet it should also be noted that the special master's hope that Coney Island be revitalized is largely unrealized. The area is still a racially isolated urban slum. 


\section{B. Organization Theory Applied to Hart}

In the end, Judge Weinstein, a most astute jurist, achieved his objective of desegregating Mark Twain. But he did so only after a lengthy process, at first supporting and later retreating from the comprehensive housing approach. Had the court employed organization theory, it might have become aware more quickly of the difficulties of implementing the comprehensive approach endorsed in the liability decision and perhaps would have concentrated sooner on the magnet school concept. By examining the remedial options-housing and educational-through the lens of organization theory, the utility of the framework described above ${ }^{117}$ in raising a judge's consciousness and in prescribing a systematic approach to relief can be demonstrated.

\section{The Housing Option}

In assessing the appropriate housing strategy with the guidance of organization theory, the court would have to consider the missions and goals of the various housing authorities. It would realize that to alter existing policy, it must effect changes in the missions of those bureaucracies. The city agency's primary mission is to provide dwellings for the poor. ${ }^{118}$ If the court were to adopt a solution like that of the special master, the agency would be required to redirect its efforts toward middle-income family housing-a policy clearly contrary to the organization's mission. Organization theory suggests that the court would almost certainly encounter resistance from housing officials.

Moreover, in relating the goals of the contemplated housing policy to the bureaucracies charged with administering housing programs, the court would quickly confront a major obstacle: overcoming sharp differences among the housing authorities over the way to achieve the goal of integrated housing. Finally, an assessment of the financial means needed to achieve the goals, as called for by organization theory, could only raise doubts in the judge's mind about the enterprise: the resource requirements would be massive and some attempt would have to be made to determine whether funds were available.

Organization theory would also lead the judge to identify the players in the housing game, and to assess their positions and power bases. The court could not fail to take note of the negative reaction of key housing officials at city, state, and federal levels to the comprehensive approach. Without the support of at least some bureaucratic elements-

117. See pp. 519-25 supra.

118. See Starr \& Zucotti, supra note 107 , at $535-46$ (discussing role of housing agency). 
and apparently there was none-the judge would no doubt face substantial problems.

In addition, a court applying organization theory could not but be impressed with the enormousness of the task of restructuring housing policy. The court would realize it would have to approve and monitor the building and location of residential and commercial development, supervise construction of new dwellings, specify the kinds of housing units, and review the tenant selection process. Given the complexity and nonroutine nature of such tasks, as well as the scope of the enterprise, the court would have to expend years of effort both planning and monitoring performance to ensure compliance. ${ }^{110}$

The theory would also immediately reveal that changing housing policies would involve the court in a massive coordinating effort. Before the housing plans could be implemented, three levels of government-federal, state, and local-would have to reach some agreement as to policy, procedures, and funding. The court would have to resolve disputes among these officials that surfaced during hearings on the special master's report. Furthermore, it would have to coordinate not only the activities of three levels of government but also the behavior of various bureaucracies within each level. At the city level alone, for example, the Housing and Development Administration, the City Planning Commission, the Department of Real Estate, and the Corporation Counsel would have to reach some consensus regarding housing policy. But each bureaucracy-as organization theory teachestends to be jealous of its autonomy and would therefore be likely to resist any arrangement that could infringe upon its ability to set its own course. Besides overseeing the activities of government, the court would have to coordinate the behavior of contractors, planners, and foundations.

Remaking housing policy on the scale envisioned by the judge in his liability decision and subsequently by the special master also would have involved external factors crucial to effective implementation but over which the court had little control. The court's efforts probably could not succeed without the cooperation of the legislatures that control appropriations and set policy. Yet, there could be no guarantee that the many political bodies at the federal, state, and local levels could or would be responsive to the court's plan.

Consideration of external forces would also lead the court to assess

119. Curtis Berger, who championed the housing plan, later recognized that it would have been infeasible for the court to have been involved in an enterprise requiring so much supervision. See Berger, supra note 101, at 735. 
the views of the local residents who might be uprooted if the comprehensive housing approach were accepted. A court would realize that it would probably not achieve its ends over the vehement objections of public housing residents-opposition that actually was heard at the hearings. ${ }^{120}$ Certainly, local political officials would be unlikely to endorse and lobby for the housing efforts if their constituents rejected the scheme. Thus, the factors applied by organization theory to explain bureaucratic behavior would lead a court to reject implementation of a housing plan. The court in Hart did, finally, reach the result that organization theory suggests. However, it did so only after long months of study. An initial evaluation of the plan using the theory would probably have saved the court and the parties time and effort.

\section{The Educational Options}

Just as organization theory would sensitize a judge to the mammoth difficulties of a housing remedy from the very beginning of his search for workable relief, so the framework would educate him about the practical results attainable if the remedial problem were defined in terms of desegregating one school. To be sure, converting Mark Twain into a magnet facility would involve considerable work on the part of school authorities. Looking ahead, however, the judge would recognize that implementation of the plan would be facilitated because the court would not have to change the educational bureaucracy's mission of teaching teenage children.

A judge applying organization theory would conclude that the magnet school strategy was promising because it would enable the court to posit the goal of integration unambiguously, and in a way that would permit measurement of progress toward that goal's realization: integration would be achieved when Mark Twain met the majority-minority ratio that existed in other district schools. Thus, a court could assess progress toward implementation without difficulty. If the school did not meet the specified ratio within the time set by the court, then the plan would not achieve the integration goal and the court could impose an alternative strategy.

In addition, organization theory would prompt the court to become familiar with the power structure of the local school board. On reviewing the testimony of various school board members in hearings at the liability stage, the judge would determine that there were members sympathetic to his integration goals, the bloc supporting a magnet

120. See p. 531 \& note 108 supra. 
school plan. ${ }^{121}$ By applying the concept, the court could effectively bolster those forces, secure their cooperation in the implementation process, and thereby increase the likelihood of success.

The theory next would lead the court to identify the kind of tasks its remedy would impose on the bureaucracy affected. The tasks required to carry out the integration plan in Hart-designing new educational programs for Mark Twain, phasing out special programs in other schools, and publicizing the new magnet facility-were relatively familiar ones for the educators involved. Indeed, many of these tasks could be regarded as routine. School personnel would not have to design new curriculums for Mark Twain, but rather simply transfer existing special programs from other district schools. Tasks like scheduling classes would be routinely performed at Mark Twain regardless of whether the educational program was standard or accelerated. Thus, once the magnet school plan was accepted, the court would not find it necessary to supervise closely the performance of tasks. Moreover, by confining itself to the educational plan, the court would have to deal with only one bureaucracy, and thus would avoid the difficulties of coordinating disparate bureaucracies, each protective of its autonomy.

Finding adoption of the plan supported by internal factors, the court would then consider the impact of its proposal on external forces. The magnet plan would be an attractive option because its implementation would not depend on the funding actions of legislative bodies beyond the court's authority. The magnet plan would be relatively inexpensive to implement, and maintenance of the magnet facility would not require much more funding than a standard school. In addition, the magnet school plan, compared to other alternatives, would seem more likely to secure community acceptance. ${ }^{122}$ Thus, analysis of the magnet school plan in terms of organization theory's framework of internal and external factors would make the judge cognizant of the best approach for attaining the desegregation objectives as well as enable him to identify problems that could arise in implementing the option.

121. See Testimony of Allen Zelon, supra note 77 , at $674-89$ (explaining politics of school board); Testimony of Allen Zelon, supra note 94, at 332-416 (school board member supporting goals of integration).

122. The liability hearings revealed, as did the special master's report, that parents might withdraw their children from public schools if the plaintiffs' busing proposals were adopted. The court would have no means of preventing parents from sending their children to nonpublic schools-an option, which if exercised, could defeat the goal of integration. 


\section{Conclusion}

Organization theory indicates-as its application to the education and housing options in the Hart case demonstrates-that a court's efforts to devise a workable remedy will be facilitated if it takes into account the internal and external factors affecting bureaucratic behavior. To be sure, there may be those who believe that in framing orders the judiciary should not be concerned with whether the remedy is likely to achieve the intended result. The objective of judicial intervention, according to this view, is not practical effectiveness at all, but the preservation of important values, as symbolized by a court's stated commitment to rectify injustice. However, for a judge who thinks that the mere articulation of rights is not sufficient, that rights cannot be exercised meaningfully if the relief is unworkable, organization theory can offer a disciplined framework that can aid in designing remedies.

As is the case with many public policy decisions, judicial orders can assume an independent dynamic and momentum that is difficult, if not virtually impossible, to reverse. One can imagine situations in which the initial actions or inactions made in error by a judge proceeding on an ad hoc basis could foreclose the subsequent imposition of other more feasible remedies. With the guidance of organization theory, a judge need not depend on the parties ${ }^{123}$ or on his intuitive sense; aided by the framework, he can better make an independent evaluation of how to define and solve the remedial problem.

In restructuring the policies and processes of public bureaucracies, courts should do so with a sensitive appreciation of how organizations function. ${ }^{124}$ Only if they act with such an understanding can courts realize their objectives. And, only then can wrongs be effectively redressed and the future exercise of rights preserved.

123. A judge should not reflexively rely on the litigants' perception of the problem for their definition may fail to lead to a result that rectifies the injuries. Indeed, had Judge Weinstein accepted the school board's initial housing strategy, see note 84 supra, and the plaintiffs' approaches, see p. 528 supra, the court might not have realized the goal of desegregation.

124. In his essay, Professor Fiss writes that "no judge is likely to decree more than he thinks he has the power to accomplish," Fiss, supra note 5, at 54, and notes that the desire to be efficacious might lead courts to tailor the rights in question to fit the remedy, thereby distorting those rights. Id. at 53-55. Where the parties' approach seems unlikely to yield practical results, the court might be tempted to retreat; organization theory is useful because it can make the judge aware of the gamut of possibilities and lead him to act creatively to assure that rights are realized. Moreover, the organization framework can reduce the likelihood that a judge will prescribe an administratively unfeasible decree that will not redress the injuries the aggrieved parties have suffered. 